\title{
Bioenergy as an Empty Signifier
}

\author{
Magdalena Kuchler and Johan Hedrén
}

\section{Linköping University Post Print}

\section{Tweet}

N.B.: When citing this work, cite the original article.

Original Publication:

Magdalena Kuchler and Johan Hedrén, Bioenergy as an Empty Signifier, 2015, Review of Radical Political Economics.

http://dx.doi.org/10.1177/0486613415591804

Copyright: SAGE Publications (UK and US)

http://www.uk.sagepub.com/home.nav

Postprint available at: Linköping University Electronic Press

http://urn.kb.se/resolve?urn=urn:nbn:se:liu:diva-121024 


\title{
TITLE
}

Bioenergy as an empty signifier

\begin{abstract}
The article provides insight into the contemporary international bioenergy debate and scrutinises how the idea of biofuel production as a win-win-win solution to energy insecurity, climate change, and agricultural stagnation came into being, what discursive forces bind such a conceptualisation, and where dislocations arise. Based on critical assumptions of discourse theory developed by Laclau and Mouffe, the analysis explores assessments, reports, policy papers, and other central documents from three influential international organisations - the International Energy Agency, Intergovernmental Panel on Climate Change, and United Nations Food and Agriculture Organization - that provide an entry point to the global debate on biofuels. We show that the bioenergy concept occupies specific positions and conveys different meanings within the three overlapping discourses of energy, climate, and agriculture. These three discursive areas are further "sutured" around the notion of biofuel production, where a hegemonic thread of the capitalist market economics, fixated on economic growth and presupposing the necessity of cost-effectiveness, results in internal contradictions and dislocations within the win-win-win conceptualisation, emptying bioenergy of any content.
\end{abstract}

\section{KEYWORDS}

bioenergy, biofuels, debate, discourse, international organisations, hegemony

\section{Introduction}

The concept of producing energy from biomass is not new, and debates about it have been resurfacing on the international agenda several times during the last century (Bernton et al., 
2010). The two most prominent moments occurred at the beginning of the $20^{\text {th }}$ century, when, in the early days of the automotive industry, biofuels were labelled as the fuel of the future and in the 1970s during the period of global energy scarcity resulting from the oil embargo declared by petroleum exporting countries. However, contrary to previous upsurges, the last two decades have witnessed a different debate that was not only driven by concerns on energy insecurity triggered by growing demand or resource scarcity. The recent global deliberations on biofuels have been marked by two more significant societal challenges: climate change impacts induced by greenhouse gas (GHG) emissions and the agricultural stagnation stemming from both excessive farming leading to overproduction in industrialised nations and depressed rural growth in developing countries.

The three challenges of energy insecurity, climate change, and agricultural stagnation can be viewed in Gramscian terms as a so-called organic crisis, which indicates that "incurable structural conditions have revealed themselves (reached maturity), and that despite this, the political forces struggling to conserve and defend the existing structure itself are making every effort to cure them, within certain limits, and to overcome them" (Gramsci, 1971:178). At stake is the legitimacy of ruling classes challenged by the crisis; consequently, these classes strive to protect the structure by imposing their domination over the entire society through what Gramsci refers to as hegemony. Central to his thought, this intervention allows policy-makers, institutions, experts, and scholars to exert their influence partly through intellectual leadership, so that society follows their political and socio-economic projects (Gramsci, 1971).

Hence, for the ruling classes challenged by the organic crisis, bioenergy appears convenient because it takes advantage of existing agricultural production patterns and outputs, requires minimal change in energy infrastructure and technology, and provides, at least theoretically, zero net greenhouse gas emissions, as any emissions released during biomass 
combustion are later reabsorbed by plants via photosynthesis. The first-generation conventional biofuels, obtained from edible plants, have been at the centre of the international bioenergy debate and have provided the largest share of biomass-derived energy globally. These include ethanol produced from sugar or starch crops and biodiesel produced from oilseed crops, other plant oil sources, or animal fat (WorldWatch Institute, 2007:13-20). The second-generation biofuels that can be obtained from inedible biomass - such as fall grasses, forestry and crop residues, and municipal waste-are less discussed as the necessary processing technologies are still under development and commercially unavailable on a large scale (WorldWatch Institute, 2007:45-53). Nevertheless, by concentrating their attention mainly on first-generation biofuels, various institutions, policy-makers, experts, and scholars have conceptualised biomass energy as, simultaneously, a renewable alternative to fossil fuels that can help reduce energy insecurity, a low-carbon mitigation option necessary to abate climate change, and a new farm product able to stimulate rural economic growth in both developed and developing countries.

The central aim of this paper is to critically analyse and unravel how the conceptualisation of bioenergy as a win-win-win solution is played out in the international debate. We expose the logic behind such reasoning by applying discourse theory of Ernesto Laclau and Chantal Mouffe (2001), which provides an important insight into how specific concepts are modified and transformed in line with or in opposition to different and often contradictory discourses. Drawing from Gramsci, the principal analytical category of Laclau and Mouffe's approach is the notion of hegemony which imposes universal logic through the societal fabric by equalising particularities of different discourses.

The perspective allows us to expose what conceptual and ideological factors lay behind the win-win-win framing, what forces bind such configuration, and where contestation arrives. It provides an insight into what has been said and how to present something that could 
potentially aggravate the crisis as a solution to the crisis. The entry point to the debate consists of assessments, reports, policy papers, and other documents issued by three major international organisations (IOs) involved in advocating for various bioenergy policies and options that result in different geopolitical, socio-economic, and environmental consequences for developed and developing countries. The selected IOs are: the International Energy Agency (IEA), Intergovernmental Panel on Climate Change (IPCC), and United Nations Food and Agriculture Organization (FAO). Despite their different agendas, structures, memberships, and functions in the global arena, our rationale for choosing them lies in the fact that each of them focuses, by mandate, on one of the three societal challenges.

Established in the 1970 s by a group of industrialised nations in the wake of the oil crisis, the IEA functions as a policy adviser to its high-income member states in the field of global energy security challenges and has a capacity to significantly influence energy policies of major governments (Keohane, 1978; Podobnik, 2006). The IPCC is a consultative body that plays a highly prominent role in assessing global scientific and socio-economic information for the climate change negotiation process, so policy-makers rely greatly on its advice with regard to the mitigation of potential climatic change (Elliott, 2004; Axelrod et al., 2005). The FAO is a specialised agency of the United Nations that serves both developed and developing nations, leading international efforts to improve agricultural productivity, provide regular access to food, and improve nutrition worldwide (Phillips, 1960).

Based on our empirical findings, we argue that due to the low-cost pressure enforced by the hegemonic system fixated on economic growth and the accumulation of capital, the concept of bioenergy becomes emptied of signification and constitutes a futile solution to the challenges of energy insecurity, climate change, and agricultural crisis. Looking more closely at the institutional discourse, our analysis reveals that, to discuss bioenergy as a potential winwin-win strategy to help solve these three societal challenges, a specific level of equivalence 
in the conceptualisation is required. What conflates the three discursive positions of bioenergy is the persuasive assumption that in each case it must be done cheaply, and whether biofuels are an efficient option to face the challenges is of secondary importance. It is because the desire to preserve economic growth and the accumulation of capital requires cheap solutions in the first place. Hence, as Peter Newell (2012) points out: "The ends of political interventions thus have to be justified in terms of their contributions to competitiveness and efficiency" (p. 52).

The paper is structured as follows. In section 2, we present our theoretical approach, which uses the theoretical assumptions of Laclau and Mouffe. In section 3, we discuss the data collection process and the analysis of empirical material. In section 4, we discuss our findings, grouped into three subsections. Finally, our conclusions are presented in section 5.

\section{Theoretical perspective}

Discourse theory developed by Ernesto Laclau and Chantal Mouffe (2001) emphasises the meaningful and dynamic character of all social configurations. The scholars argue that any process of conceptualisation rests on intersubjective relationships that are expressed in a multitude of different positions and, as a result, only partial and temporary objectivity can be reached. Differences, or antagonisms in terms of Laclau and Mouffe (2001), play a significant role in constituting a partial identity of any given concept. On the one hand, the occurrence of antagonisms is the main reason behind the impossibility of reaching a complete identity by social structures. On the other hand, it is precisely because of the failure to reach the closure of meaning that particular social structures require the presence of antagonism, the notion of otherness they can define against and constitute their partial objectivity in opposition to it.

According to Laclau and Mouffe (2001), this open and contingent character of the social constitutes a field of discursivity — a boundless and dynamic terrain of the surplus of meaning 
in which various discourses constantly overlap. Its elements have the status of floating signifiers - unstable concepts that are constantly open to interpretation and modification (Laclau and Mouffe, 2001:113). Hence, they acquire new contents as "different discourses struggle to invest with meaning in their own particular way” (Jørgensen and Phillips, 2002:28). In this sense, the concept of bioenergy has a floating character because it can mean different things to different people. For example, it can signify an "advanced" process of producing energy from algae or burning biomass in "traditional" cook stoves. It can represent a "sustainable" energy source for small-scale farmers in poor rural communities or a strategy for armed forces to go "green" by fuelling military vehicles with biofuels.

However, the theoretical approach also informs us that meanings are not only constructed through the presence of differences, but also because of the active presence of the political, understood as the exercise of power able to temporarily arrest the meaning. As Laclau (1990) explains, "the social is impossible without some fixation of meaning, without the discourse of closure" (p. 92). Thus, a given discourse becomes a dynamic force that penetrates the field of discursivity and strives to temporarily arrest the flow of floating signifiers around specific elements (Laclau and Mouffe, 2001; Andersen, 2003). The result of this partial fixating is expressed in privileged discursive signs called nodal points and is relative to other signs that are positioned and acquire their meaning (Laclau and Mouffe, 2001:112; Jørgensen and Phillips, 2002:26). In other words, at the occurrence of a powerful discourse penetrating the field of discursivity and striving to arrest the meaning, a particular floating signifier is transformed into a nodal point that occupies the centre of this discourse and around which conceptual formation is built (Smith, 1998; Jørgensen and Phillips, 2002). As we show in the analytical part of this paper, the concept of biofuel loses its floating character when powerful discourses of energy, climate, and agriculture strive to partially and temporarily anchor it as a nodal point around specific conceptual formations. 
However, no discourse can be completely closed and fully conceptualised because "it is in conflict with other discourses that define reality differently and set other guidelines for social action" (Jørgensen and Phillips, 2002:47). This incessant collision of discourses can be dissolved only through a hegemonic intervention. Resembling the character of a discursive force with its power to arrest the flow of signifiers, hegemony also strives to fix meaning but across various discourses that collide with each other (Jørgensen and Phillips, 2002:48). This action, however, requires two interrelated components. First, to suture distinctive discourses together, a hegemonic intervention employs the logic of equivalence that transcends and partially cancels differences between them. Thus, by simplifying and weakening the relational system defining the identities of competing discourses, the hegemonic intervention can bind their partly transformed particularities into a compatible sequence that Laclau and Mouffe (2001) refer to as the chain of equivalence. Second, a hegemonic intervention requires the presence of antagonism, as the process of suturing together discursive particularities, to establish the chain of equivalence between them, can only be executed through negativity "vis-à-vis oppressive forces" that outline the limits of this equivalence (Laclau and Mouffe, 2001:xiii).

Finally, Laclau (1996) contends that the very condition of hegemony is the presence of an empty signifier (p. 43) and that simply "floating of the signifier does not make it an empty one" (p. 36). In other words, the concept of bioenergy having a floating character and thus meaning different things to different people does not make it an empty one. For Laclau (1996), an empty signifier can only emerge if the signification is structurally impossible due to various distortions and interruptions within the chain of equivalence (p. 37). The reason behind such "malfunctions" is that the identity of each particular element in the chain must be partially altered to fit other elements in the configuration (Laclau and Mouffe, 2001:63). Consequently, a hegemonic empty signifier symbolises a long chain of equivalence while, 
simultaneously, being disengaged from its particular signification and thus assuming a function of universal interpretation (Laclau, 1993:342; 2000:302-303).

\section{Data collecting and processing}

The empirical data were collected and processed in three steps. Firstly, primary data spanning the 20 years from 1990 to 2010 were collected from the online databases of the FAO (www.fao.org), IEA (www.iea.org), and IPCC ( $\underline{\text { http://ipcc.ch) }}$ ) using the following search terms: "agrofuel”, “agroenergy”, “biofuel”, “bioenergy”, "biomass energy”, “biomass fuel”, "biodiesel", "biogas", "energy crop", and "ethanol". As can be seen, the preliminary search was broadly delimited to include all types of bioenergy produced from biomass to expand the scope and encompass various types of biomass production and use. Secondly, the compiled data were analysed by breaking the texts into segments and then identifying and extracting related key fragments to scrutinise how the IOs discuss and advocate bioenergy in relation to and in the context of energy, climate change, and agriculture. Comparing each organisation's treatment of the concept in the three discursive fields allows us to extract recurring patterns and group them into themes that serve as the basis for examining the concept of bioenergy in its role and function relative to the three distinct nodal points. Thirdly, the compilation of texts was analysed again to trace and unravel how the institutions forward biofuels by embedding them in the market ideology.

\section{Analysis}

In the analytical section, we first present evidence of bioenergy's loss of its floating character to privileged positions of signification as a nodal point in the three discourses of energy insecurity, climate change mitigation, and agricultural crisis. We then elaborate on how the concept is reproduced and homogenised through the chain of equivalence by the 
hegemonic thread of capitalist market economics and its commensuration process, resulting in bioenergy becoming an empty signifier.

\subsection{From a floating signifier to nodal points: partial fixating of the meaning}

As a floating signifier in a given field of discursivity, the bioenergy concept has no intrinsic meaning outside a specific discourse; instead, it is open to change and redefinition when combined with or positioned against other meanings. However, on closer examination, the concept loses its floating character when powerful discourses of energy insecurity, climate change, and agricultural stagnation arrest the signifier's flow and fix the conceptualisation around it. As a result, bioenergy acquires the privileged position of a nodal point that has a totalising effect on other elements by incorporating them into an assembled network of meaning.

\subsubsection{The challenge of energy insecurity}

The steady economic growth experienced by capitalist societies over the past 200 years is considered by many to be not only a natural state but also a trend that will continue indefinitely. The key enabler and indispensable driver of this generally desired developmental path is energy, specifically increasing quantities of fossil fuels (Ayers and Warr, 2009; Podobnik, 2006; Rogers Jr., 2000). Because the continuous availability of stable and reliable energy is a critical factor for the future global economy and the robustness of economic growth (Stern 2010), energy insecurity is the major challenge that can seriously disturb the fundamentals of the hegemonic order.

The concept of bioenergy enters the discursive field of energy to function as a nodal point in the form of a potential alternative to hydrocarbons and as a solution to the looming energy crisis. Its plausibility comes not so much from the fact that it is renewable and therefore 
inexhaustible, but mostly from the abundance of accessible biomass worldwide and because the implementation of such energy does not require significant changes in the existing infrastructure of capitalist societies. Hence, as the nodal point, bioenergy holds the promise of securing and diversifying energy supplies without altering the hegemonic order.

The IEA, FAO, and IPCC all promote biomass as renewable based on the theoretical assumption that plant material stores solar energy that lasts indefinitely (FAO 1994, 2008a,e; FAO/GBEP 2007; IEA 1994, 1997a,b, 2003a, 2004a,d,e, 2006b, 2007a, 2008b, 2010; IEA Bioenergy 2006c,e, 2008b; IPCC 1995, 2001a,b,c,e; WEC/FAO 1999). Simultaneously, the IOs position biomass not only as renewable but also as an alternative source of energy, suggesting that it can play a pivotal role in displacing fossil fuels (FAO 2005, 2007b,c,d, 2008b,e,i; FAO/IIED 2008; IEA 1994, 1997a, 2002, 2003b, 2004a,e, 2005, 2006b,c, 2008b; IEA Bioenergy 2002, 2005a, 2007; IPCC 1990, 1995, 2001b,c, 2007b,d), alleviating dependence, particularly on oil in the transportation sector, without the need to change existing infrastructure (Cohen et al., 2008; FAO 2008b,e,i, 2009a; FAO/GBEP 2007; FAO/IIED 2008; IEA 1994, 1998, 2003b, 2004a, 2006c, 2007a, 2008a, 2010; IEA Bioenergy 1998, 2005b, 2007; IPCC 2007b; OECD/FAO 2007), and diversifying energy resources (FAO 2005, 2008i; FAO/GBEP 2007; IEA 1994, 2003a, 2006c; IEA Bioenergy 2006d,e, 2007). The notion of biomass as a renewable substitute for hydrocarbons extends to the conceptualisation of bioenergy as an energy source that can provide access to energy in general and help us meet global energy demand (FAO 2005, 2008d; Heinimö et al., 2007; IEA 1997a, 2001, 2003b, 2006b, 2007a, 2010; IEA Bioenergy 1998, 2008a; IPCC 1995, 2007b) and, therefore, ensure energy security (FAO 1994, 2005, 2007a,c, 2008a,b,e,i,j, 2009a; FAO/GBEP 2007; Heinimö et al., 2007; IEA 2000b, 2003a, 2004a, 2006c, 2007a, 2008a, 2010; IEA Bioenergy 2005b, 2006b,c,e, 2007, 2008a,b; IPCC 2007a,b; Junginger et al., 2010). 
For example, the IEA states that "one of the arguments for using biofuels is that they are potentially a renewable form of energy and most countries have some potential for producing them indigenously" (IEA 1994:14). The Agency argues that "biofuels for transport, including ethanol, biodiesel and several other liquid and gaseous fuels, have the potential to displace a substantial amount of petroleum around the world over the next few decades, and a clear trend in that direction has begun" (IEA 2004a:11). In another report, the Agency concludes that "biomass may diversify the total portfolio of fuels used and imported by countries, thereby reducing the risks of supply disruption in terms of both quantity and price, especially in the case of biofuels for transport since they replace oil imports" (IEA Bioenergy 2005b:9). The IPCC considers biomass a renewable energy technology and recognises its increased use as a way to replace fossil fuels (IPCC 2001c:131). The Panel envisages that "bioenergy options will be important for many sectors by 2030 , with substantial growth potential beyond" (IPCC 2007b:621). In particular, "biofuels used as gasoline and diesel fuel additives/substitutes are projected to grow to $3 \%$ of total transport energy demand in the baseline in 2030 " and "this could increase to about 5-10\%" (IPCC 2007d:13). According to the FAO, "biomass is a locally available energy source that can produce electricity, heat and power, based on liquid, gas, or solid-derived fuels, which can contribute to the substitution of imported fossil fuels, thus enhancing national energy security as well as the diversification of energy sources" (FAO 2005:2). Moreover, the Agency states that "bioenergy is seen as one means of diversifying sources of energy supply and reducing dependency on a small number of exporters. Liquid biofuels represent the main alternative source that can supply the transport sector, which is overwhelmingly dependent on oil, without more radical changes to current transport technologies and policies" (FAO 2008i:26).

\subsubsection{The challenge of climate change}


Climate change and the threats it poses to the future prosperity and stability of civilisation present yet another challenge that contemporary capitalist societies and their ruling classes must face. In its Third Assessment Report, the IPCC states that climate change is likely to have "numerous negative effects on human development and well-being" (IPCC 2001a:84). Published in 2006, the Stern Report goes even further in its warning, linking risks associated with climate change directly to economic growth, based on the assumption that the capitalist accumulation necessary to continuously save and invest in the economy could be significantly reduced by the negative impacts of climate change (Stern et al., 2006).

Against the backdrop of climate change as a threat to the stability of capitalist societies and their capacity to accumulate wealth and continue along the developmental path, bioenergy enters this particular discursive formation to acquire the role of yet another privileged sign around which meaning coalesces. As the nodal point, energy produced from biomass is recognised by all three institutions as a key mitigation technology that can have a significant role in climate change abatement efforts and help meet targets defined by the Kyoto Protocol (FAO 1994, 2005, 2006, 2007a,b, 2008b,c,i; FAO/GBEP 2007; FAO/IIED 2008; IEA 2004a; IEA Bioenergy 2005b, 2007, 2008a; IPCC 2001b, 2007b,c,d). This realisation is possible because the IOs all assume that bioenergy has the potential to significantly reduce GHG emissions (FAO 2007a,c, 2008e,i,j, 2009a,b; FAO/GBEP 2007; Heinimö et al., 2007; IEA 1994, 1997b, 2000b, 2001, 2003b, 2004a, 2006c, 2007a, 2008b; IEA Bioenergy 1998, 2002, 2005a,b, 2006e, 2007; IPCC 2001c,e, 2007a,b,d,e; OECD/FAO 2007; Rapsomanikis and Hallam, 2006). The emphasis is placed on biofuels' ability to diminish carbon dioxide $\left(\mathrm{CO}_{2}\right)$ emissions in the transportation sector (FAO 1994, 2007d, 2008e; IEA 1994, 1997a, 2003a, 2004a,e, 2009, 2010; IEA Bioenergy 1998, 2002, 2005a,b, 2006a; IPCC 1990, 1995, 2001b, d,f, 2007a,b; Rapsomanikis and Hallam, 2006). Consequently, the IOs portray biomass as a carbon-neutral energy source that, unlike conventional fossil fuels, ensures low- or zero- 
carbon energy (FAO 2005, 2006, 2007c, 2008i; FAO/GBEP 2007; IEA 1994, 1997b, 1999, 2001, 2002, 2003a, 2004a,b,c, 2006a,c, 2007a, 2010; IEA Bioenergy 2002, 2005b, 2006b; IPCC 1990, 2001b,c, 2007b).

To illustrate this, the IEA suggests that "biofuels can play a significant role in climate change policy and in measures to reduce GHG emissions. Biofuels have become particularly intriguing because of their potential to greatly reduce $\mathrm{CO}_{2}$ emissions throughout their fuel cycle. Virtually all of the $\mathrm{CO}_{2}$ emitted by vehicles during combustion of biofuels does not contribute to new emissions because the $\mathrm{CO}_{2}$ is already part of the fixed carbon cycle" (IEA 2004a:20). In another document, the Agency states that biomass is "a carbon-neutral energy source on that basis, as it releases only the $\mathrm{CO}_{2}$ that was captured during its growth and an equivalent amount of $\mathrm{CO}_{2}$ is recaptured in the regrowth. In that sense, biomass can greatly contribute to $\mathrm{CO}_{2}$ emissions reductions, relative to fossil fuel use" (IEA 2010:284). In its scientific assessment, the IPCC considers biomass low-carbon energy and argues that "a high potential supply of biomass energy would ameliorate the burden of carbon emissions reduction" (IPCC 2001b:160). Moreover, the Panel suggests that "such fuels release $\mathrm{CO}_{2}$ when burned, but this $\mathrm{CO}_{2}$ is of recent atmospheric origin (via photosynthetic carbon uptake) and displaces $\mathrm{CO}_{2}$ which otherwise would have come from fossil carbon" (IPCC 2007b:511). Like the other IOs, the FAO suggests that energy produced from biomass is a "potentially important source of carbon emissions reduction" (FAO 2007d:43) and that the capacity for bioenergy to reduce GHG emissions is well recognised (FAO 2008e:44). In one report, the organisation states that "when sustainably produced, biofuels can provide a carbon-neutral or even carbon-reducing source of energy. Biofuels can contribute to climate change mitigation through substituting for fossil fuels and through carbon sequestration in forest and soils" (FAO 2007a:10). Furthermore, the UN agency reasons that such potential is attainable because "biofuels are produced from biomass; in theory, therefore, they should be carbon 
neutral, as their combustion only returns to the atmosphere the carbon that was sequestrated from the atmosphere by the plant during its growth—unlike fossil fuels, which release carbon that has been stored for millions of years under the surface of the earth" (FAO 2008i:17).

\subsubsection{The challenge of the agricultural crisis}

The potential agricultural crisis presents a more complex challenge to capitalist societies, because the fate and shape of global food production is strictly interwoven with the two previously discussed challenges. In developed nations, where only a small fraction of the population works on farms and food production is highly industrialised, excessive farming has led to chronic surplus production that in turn depresses prices on basic commodities and causes stagnation in the sector (Gardner, 1996). In contrast, developing countries-where most poor populations live in rural areas and depend on agriculture-experience depressed rural growth and are particularly vulnerable to famines (Cuffaro, 2001; Weis, 2007). Agricultural production is not just essential to human survival, livelihoods, and quality of life. It is also vital to the hegemonic order of capitalist societies fixated on capital accumulation and economic growth. The underlying reason for this, as Johnston and Mellor (1961) explain, is that "economic development is characterized by a substantial increase in the demand for agricultural products, and failure to expand food supplies in pace with the growth of demand can seriously impede economic growth" (p. 571). Any potential crisis in the global rural sector threatens the stability of capitalist societies and their continuous ability to accumulate capital and continue along the developmental path.

Therefore, when bioenergy enters the discursive field of agriculture, the concept is transformed into a key enabler of an indispensable factor promoting rural economic development in both developed and developing countries. The IOs suggest that, by creating employment and providing new jobs (Cohen et al., 2008; FAO 1994, 2006, 2007b, 
2008a,b,f,i,j, 2009a,b; FAO/GBEP 2007; FAO/IIED 2008; IEA 1994, 2007a, 2010; IEA Bioenergy 1998, 2002, 2004, 2005a, 2006a,b,c,e, 2007; IPCC 1995, 2007b; Schmidhuber 2006), bioenergy will enable farmers to earn greater income (Cohen et al., 2008; FAO 1994, 2006, 2007a,b,c, 2008a,b,e,f,i, 2009a,b; FAO/GBEP 2007; FAO/IIED 2008; IEA 2004a; IEA Bioenergy 2004, 2005a,b, 2006a,e; IPCC 1995, 2007b; Schmidhuber, 2006). These organisations argue that production of energy from biomass can help revitalise the agricultural sector and promote rural development (FAO 1994, 2006, 2008b,c,d,e,f,g,i, 2009a,b,c,d; FAO/GBEP 2007; FAO/IIED 2008; IEA 2004a, 2006b,c, 2007a,b, 2008a; IEA Bioenergy 2004, 2005a,b, 2006a,b,d, 2007; Junginger et al., 2010; Schmidhuber, 2006). Moreover, in particular, the FAO and IEA argue that bioenergy constitutes a new product able to increase demand for feedstocks (FAO 2006, 2008c,g,i, 2009a; IEA 1994, 2004a; IEA Bioenergy 2005b, 2006b,e; Schmidhuber, 2006) and, as a result, improve yields and food security (Cohen et al., 2008; FAO 1994, 2008b,d,g,i; FAO/IIED 2008).

To exemplify this, the IEA argues that "from the social perspective there can be little doubt that bioenergy projects protect existing employment, provide new jobs, give learning opportunities, transfer skills, introduce new skills, and provide training and educational opportunities" (IEA Bioenergy 2002:4). According to the Agency, "unlike other renewable energy sources, the production and use of bioenergy is relatively labour intensive and can potentially play a positive role in maintaining and developing the rural economy" (IEA Bioenergy 2008a:2). In another report, the Agency also suggests that spatial expansion of bioenergy production would offer many opportunities for farmers internationally, as "the possibilities for exporting biomass-derived commodities to the world's energy markets can provide a stable and reliable demand for rural communities in many (developing) countries, thus creating an important incentive and market access that is much needed in many areas of the world" (IEA Bioenergy 2005b:7). The IPCC assumes that "the increased production of 
biofuels for transportation, or energy production in rural areas, is expected to protect existing employment and to create new jobs in rural areas" (IPCC 2007b:730-731). Furthermore, the IPCC assesses that "large-scale production of modern bioenergy crops, partly for export, could generate income and employment for rural regions of world" (IPCC 2007b:522). According to the FAO, "potential benefits associated with bioenergy production include increased employment opportunities and related improvement in livelihoods. Bioenergy may contribute to job creation and higher wages in agricultural communities by diversifying rural economies. Developing countries in particular have much to gain from increased global demand for biofuels if they can diversify their agricultural output with energy crops, especially if they can grow feedstocks that may be used for both food and fuel markets" (FAO 2007b:22). In another document, the UN agency also suggests that "the expanding market for biofuel feedstock offers a new opportunity for agricultural producers, and could contribute significantly to higher incomes for farmers and farm workers who are well-placed to take advantage of the opportunity" (FAO 2007a:12). Therefore, as the FAO argues, "the demand for biofuels could reverse the declining trend in real commodity prices that has depressed agricultural growth in much of the developing world over recent decades. As such, biofuels may offer an opportunity for developing countries-where $75 \%$ of the world's poor depend on agriculture for their livelihoods-to harness agricultural growth for broader rural development and poverty reduction" (FAO 2008i:5-6).

\subsection{Reproducing the concept in the chain of equivalence: an empty signifier}

The struggle to provide discursive closure to bioenergy as a win-win-win solution to the three syndromes of the organic crisis depends on a level of equivalence between the specific nodal positions it occupies in three distinct discourses. The hegemonic intervention is driven by the necessity of assembling the three particularities of the concept into an equivalent 
relationship with each other - and most importantly — in opposition to antagonistic forces that could threaten the dominant order fixated on economic growth and capital accumulation. As a result, the capitalist logics of price pressure and cost-effectiveness become measurement characteristics that, depending on the values they express, place bioenergy in a position that can be either commercially beneficial or disadvantageous, regardless of the concept's occupation of privileged centres in the three discursive formations.

Therefore, by suturing its meaning with the hegemonic thread by the logic of the capitalist market economy, the three nodal positions of bioenergy become homogenised through a process of commensuration. Furthermore, they are placed in the chain of a valuing system that partially reproduces the concept's quality as a feasible solution to specific problems into that of a commodity that, by acquiring economic feasibility, can be regarded as useful and functional. In other words, whether bioenergy is potentially an effective way to deal with the challenges of energy insecurity, climate change, and agricultural crisis is of secondary importance now. In the equivalent network sutured through the hegemonic thread, what primarily matters is bioenergy's cost-effectiveness, and that is what explicitly determines its competitiveness on the market and its significance as an alternative option. Consequently, the totality of cost and price pressures transforms a bioenergy option that is too expensive to go into commercial production into an antagonistic force that can impose oppression on the hegemonic system. It is the cheap solution preserving the economic growth and capital accumulation that is desired and accepted.

The hegemonic thread that sutures the concept of bioenergy into the chain of equivalence is obvious in documents and reports issued by the IOs, since the process of commensuration is ubiquitous. All international organisations depict the bioenergy option as a potentially costeffective strategy that could cheaply replace fossil fuels, mitigate climate change, and revitalise agriculture (FAO 1994, 2005, 2007b, 2008i, 2009d; FAO/GBEP 2007; IEA 1994, 
1997a, 2004a, 2004c, 2007a; IEA Bioenergy 2006e; IPCC 2007b,e). On closer inspection, however, one crucial problem arises when forming the equivalent chain and repositioning its links to fit each other. When the economic feasibility of producing energy from biomass is compared with that of fossil fuels, in particular oil, the institutions realise that the actual costs of bioenergy remain unfavourable and must be subsidised to make this energy more competitive on the market (FAO 1994, 2005, 2007a,d, 2008e,h,i; FAO/GBEP 2007; IEA 1994, 1995, 1997b, 1999, 2000a, 2001, 2002, 2003b, 2004a, 2006b, 2008a,b, 2010; IEA Bioenergy 2004, 2006d, 2007; IPCC 1990, 2001b, 2007b,e; Rapsomanikis and Hallam, 2006). The IEA notes that "high cost is the primary barrier to all biofuels" (IEA 2000a:59). According to the FAO, "decreasing the price differences between fossil fuels and biofuels remains a major general constraint when these prices are based on direct cost analysis, even when the recent volatility in international oil prices is making bioenergy (and raw materials produced from biomass) more attractive" (FAO 2005:3). For the IPCC, especially "transport biofuel production costs remain high compared with oil products" (IPCC 2001b:173).

As a result, it is not only that bioenergy as a final product per se must be cost-effective, but that the hegemonic chain of equivalence must extend to encompass the other aspects of bioenergy, including the economic cost of production (IPCC 1990, 2001b, 2007b,e), relating directly to the cost of the feedstock from which the energy is produced (FAO 1994, 2007a, 2008i; IEA 1994, 1999, 2001, 2004a, 2006b,c; IEA Bioenergy 2006e; IPCC 2001b, 2007b; Rapsomanikis and Hallam, 2006; Schmidhuber, 2006), which further corresponds to the cost of labour necessary to harvest and process biomass (FAO 1994; IEA 1999, 2004a, 2006c; IEA Bioenergy 2005b, 2006b,e, 2007; Schmidhuber, 2006). For example, the IEA observes that "the main cost element in biofuel production is the feedstock, so research currently concentrates on the identification of cheaper feedstocks to reduce the costs of fuel production and help make it more competitive with fossil fuels" (IEA 2001:326). Similarly, the FAO 
states that "biofuel production costs depend fundamentally on the underlying production costs for the feedstock, so low-cost agricultural producers are also more likely to be low-cost producers of bioenergy" (FAO 2007a:10-11). Since the price of bioenergy must be reduced to make it competitive with fossil fuels on the capitalist market, these institutions assume that lowering the cost could be achieved and propose three different ways to do so.

Firstly, the IOs suggest that to make the bioenergy option cost-effective, it must be supported by government in the form of various subventions (FAO 2008i, 2009b; FAO/GBEP 2007; Heinimö et al., 2007; IEA 1994, 2001, 2002; IEA Bioenergy 2005a, 2006d; IPCC 2001b; OECD/FAO 2007; Rapsomanikis and Hallam, 2006). Accordingly, the IEA reasons that biofuels are only competitive if they enjoy subsidies (IEA 2001:310). The FAO justifies this position by arguing that biofuels "without subsidies are currently not competitive with their (also subsidized) fossil fuel counterparts, with the exception of Brazilian sugarcane ethanol" (FAO/GBEP 2007:40). In its assessment report, the IPCC argues similarly that biofuels can only become competitive with cheap oil if "significant government support is provided" in the form of, for example, "subsidies (such as for use of set-aside surplus land)" (IPCC 2001b:245).

Secondly, the institutions advocate for intensification of global agricultural production — by achieving higher yields, establishing large-scale cultivation schemes, and introducing technological innovations - as yet another way to meet the price pressure and make the bioenergy option cost-effective (Cohen et al., 2008; FAO 1994, 2007a,b, 2008a,e,f,g,i, 2009a; FAO/GBEP 2007; Heinimö et al., 2007; IEA 1994, 1997a,b, 2000a,b, 2001, 2003a,b, 2004a,c,d,e, 2005, 2006b,c, 2007a, 2008a, 2010; IEA Bioenergy 1998, 2006b; IPCC 2007b). The IEA suggests that "with increased productivity, energy crops could also provide a lowcost fuel for producing” (IEA 2001:402). Moreover, in the Agency's view, "one way to increase the benefits and lower the costs of producing biofuels is to raise crop yields" because 
"high crop yields per acre and per energy input (like fertiliser) reduce cost, increase potential biofuels supply" (IEA 2004a:47). The FAO argues that "given the significant economies of scale associated with biofuel feedstock production, in most cases large-scale plantations represent the most efficient and economically competitive option for producing such feedstock" (FAO 2008f:3). According to the FAO, "improved crop yields, area expansion and intensification could expand feedstock production significantly and reduce costs" (FAO 2008i:6). The IPCC suggests that "in the years to come, some biofuels may become economically competitive, as the result of increased biomass yields" (IPCC 2007b:344).

Thirdly, all three organisations recommend that to alleviate price pressure and make the bioenergy strategy more cost-effective, it is necessary to expand the production of biomass for energy to developing countries characterised not only by suitable climatic conditions but, most importantly, cheap labour and land (FAO 1994, 2007a, 2008b,e,f,i, 2009a,b,d; FAO/IIED 2008; IEA 2003a, 2004a,c,d, 2006c; IEA Bioenergy 2005b, 2006b,e, 2007; IPCC 2007b; Rapsomanikis and Hallam, 2006). The IEA argues that "if developing countries can make use of their substantial biomass supplies by cost-effectively converting them to biofuels, they can benefit from trade with OECD countries" (IEA 2003a:37). Moreover, "given the availability of land and relatively low costs of labour in many developing countries, biomass production costs can be low, and thus offer an opportunity to export biomass-based energy carriers to developed countries" (IEA Bioenergy 2006b:3). The FAO concurs with this idea, stating that "in the longer-term, tropical countries will likely play an increasingly important role in feedstock production, due to favourable biophysical conditions and generally lower costs of land and labour" (FAO 2008b:15). In another report, the FAO similarly implies that "tropical and subtropical countries not only have land and climatic conditions suitable for the efficient crop production of many important feedstocks, but their labour costs are usually lower than in OECD countries" (FAO 2009b:2). The IPCC promotes much the same assertion 
by suggesting that "major transitions are required to exploit the large potential of bioenergy" and therefore "improving agriculture efficiency in developing countries is a key factor" (IPCC 2007b:511).

However, the signification of the bioenergy concept as reproduced by the hegemonic thread symbolises a long chain of equivalence that, due to internal distortions, can no longer hold its structure. Unavoidable alternations applied to particular identities of the discursive moments to establish a sequence of compatibilities in relation to antagonistic forces contradict the privileged position that bioenergy occupies as the nodal point in the three discourses. Hence, various intrinsic dislocations mark the impossibility of conceiving what is within the given limits of signification.

Firstly, the problem with subsidies is that they are often too costly (Steenblik, 2007), which positions them antagonistically in the chain of equivalence, outside the systemic limits set up by the hegemonic intervention. Additionally, financial support provided by governments for bioenergy production distorts agricultural markets domestically and internationally, making it a highly contested issue in the debate. Secondly, and most importantly, it is the implications of the intensification and expansion of biomass production to reduce the cost that mark the limitations of the conceptualisation of bioenergy as a win-win-win solution to the three symptoms of the organic crisis. Basing production on economies of scale and the further spatial enlargement of cultivation entails such problematic issues as: increased fossilisation through expanded mechanisation and extensive fertilizer and pesticide use; massive direct and indirect land use changes; concentration of land and production ownership; and reduction in rural manual labour (Kuchler and Linnér, 2012). These factors, in turn, call into question: the extent to which biofuels can serve as a renewable energy source able to reduce dependence on oil and contribute to energy security; how the concept can be claimed to be carbon dioxide neutral to help reduce GHG in climate change mitigation efforts; and how the bioenergy 
strategy can provide rural jobs, improve farmers' incomes, and promote agricultural development.

Marked by internal contradictions and dislocations in the chain of equivalence, the winwin-win construction is disengaged from particular significations and results in emptying the concept of bioenergy of any precise content. Consequently, the bioenergy option constitutes emptiness that serves both as a brilliant solution to the three challenges of the organic crisis and pretty much nothing at all or, more precisely, preservation of the status quo. Worse, it presents something that could potentially aggravate the crisis rather than help overcome it. However, this emptiness of the concept is a necessary condition for the hegemonic discourse to succeed. Hence, it is an expression of powerful discursive means that make it possible for the logic of a capitalist market economy to secure its continuation through hegemonic sedimentation that establishes and grounds a particular norm expressed through economic growth and capital accumulation.

\section{Conclusions}

As demonstrated in the analytical section, the bioenergy concept is not empty per se, but becomes emptied because of the hegemonic project's attempt to suture its signification through the logic of a capitalist market economy fixated on economic growth and capital accumulation. We argue that, as shaped and forwarded in the current international debate, the bioenergy option constitutes a futile way to deal with the three symptoms of the organic crisis, due to the pressure of the same market ideology that initially caused these problems. Simultaneously, the international debate illustrates that dominant voices serve to sediment the capitalist economy rather than respond to the urgent need for serious structural reforms demanded by the three challenges of energy insecurity, climate change, and agricultural 
stagnation. Prominent international organisations (i.e., the IEA, IPPC, and FAO) appear to play a significant role in providing the ideological grounds for such hegemonic interventions.

From an environmental justice perspective, it is apparent that this hegemonic project maintains the production of uneven geographical differences (Harvey, 1996:5). The necessity of low production costs and low-priced bioenergy commodities excludes any concerns about improving welfare or prohibiting environmental degradation in poor areas. Rather than presenting solutions to the organic crisis, the project confirms and presupposes the continuance of current environmental deprivation in the global south and uneven economic relationships globally. While we could have expected the discourses to contain seeds of utopian thought, expanding on specific bioenergy potentials (e.g., flexibility, small scale, and local adaptability), we find instead the emptiness of ideological mystification, taking the current control and distribution of wealth and resources for granted.

The potential utopian energies are still to be released here (Hedrén and Linnér, 2009), particularly regarding any radically alternative structural settings. Experimental activities prompted by social unrest and the triple crisis (i.e., the economy, the environment, and food supply) are developing in a great number of settings and directions today. One example is the engagement in strategies for de-growth, which means downscaling of production and consumption in combination with increased well-being and enhanced equity and environmental conditions (Sekulova et al., 2013). Other examples can be found in different manifestations of the so-called peer economies: peer-to-peer hardware production and peerto-peer consumption of goods (Bradley, forthcoming). Any endeavour to include bioenergy in such experiments should of course relate to the unsustainability of an oil-driven economy to alternatives in which justice and ecological considerations are as important as material wealth and social welfare. 


\section{REFERENCES}

Andersen, N. A. 2003. Discursive Analytical Strategies: Understanding Koselleck, Laclau, Luhmann. Bristol: The Policy Press.

Axelrod, S., D. L. Downie, and N. J. Vig. 2005. The Global Environment: Institutions, Law and Policy, 2nd ed. Washington, DC: CQ Press.

Ayers R. U., and B. Warr. 2009. The Economic Growth Engine: How Energy and Work Drive Material Prosperity. Cheltenham, UK and Northampton, MA: Edward Elgar.

Bernton, H., B. Kovarik, and S. Sklar. 2010. The Forbidden Fuel: A History of Power Alcohol. Bison Press, Lincoln, Nebraska, USA.

Bradley, K. Forthcoming. Towards a peer economy: How open source and peer-to-peer architecture, hardware, and consumption are transforming the economy. In Bradley, K. \& Hedrén, J. Green Utopianism: Politics, perspectives and micro-practices, London, UK: Routledge.

Cohen M. J., C. Tirado, N-L. Aberman, and B. Thompson. 2008. Impact of Climate Change and Bioenergy on Nutrition. Rome: IFPRI and FAO.

Cuffaro, N. 2001. Population, Economic Growth and Agriculture in Less Developed Countries. London and New York: Routledge. 
Elliott, L. 2004. The Global Politics of Environment, 2nd ed. New York: New York University Press.

FAO. 1994. Bioenergy for Development: Technical and Environmental Dimensions. Prepared by Woods J and D O Hall. FAO Environment and Energy Paper \#13. Rome: FAO.

FAO. 2005. Bioenergy. Item 7 of the Provisional Agenda, Committee on Agriculture, Nineteenth Session. COAG/2005/7. Rome: FAO.

FAO. 2006. Energy and Gender Issues in Rural Sustainable Development. Prepared by Y Lambrou and G Piana. Rome: FAO.

FAO. 2007a. Assessment of the World Food Security Situation. Committee on World Food Security, Thirty-third Session. CFS:2007/2. Rome: FAO.

FAO. 2007b. Recent Trends in the Law and Policy of Bioenergy Production, Promotion and Use. Prepared by C. Jull, P. C. Redondo, V. Mosoti and J. Vapnek. FAO Legislative Study \#95. Rome: FAO Legal Office.

FAO. 2007c. Report of the 33rd Session of the Committee on World Food Security (Rome, 710 May 2007), Hundred and Thirty-second Session. Rome, 18-22 June 2007. CL 132/10. Rome: FAO.

FAO. 2007d. The State of Food and Agriculture: Paying Farmers for Environmental Services. Rome: FAO. 
FAO. 2008a. Bioenergy, Food Security and Sustainability: Towards an International Framework. High-Level Conference on Food Security: The Challenges of Climate Change and Bioenergy. Rome, 3-5 June 2008. HLC/08/INF/3. Rome: FAO.

FAO. 2008b. Bioenergy and Land Tenure: The Implications of Biofuels for Land Tenure and Land Policy. Rome: FAO.

FAO. 2008c. Bioenergy Policy, Markets and Trade and Food Policy. Technical background document from the Expert Consultation, Rome, 18-20 February 2008. Rome: FAO.

FAO. 2008d. Climate Change, Bioenergy and Food Security: Options for Decision Makers Identified by Expert Meetings. High-level Conference on World Food Security: The Challenges of Climate Change and Bioenergy. Rome, 3-5 June 2008. HLC/08/INF/5. Rome: FAO.

FAO. 2008e. Forests and Energy: Key Issues. FAO Forestry Paper, 154. Rome: FAO.

FAO. 2008f. Gender and Equity Issues in Liquid Biofuels Production: Minimizing the Risks to Maximize the Opportunities. Prepared by A Rossi and A Lambrou. Rome: FAO.

FAO. 2008g. Opportunities and Challenges of Biofuel Production for Food Security and the Environment in Latin America and the Caribbean. Thirtieth Regional Conference for Latin America and the Caribbean. Brasilia, Brazil, 14-18 April 2008. LARC/08/4. Rome: FAO. 
FAO. 2008h. Soaring Food Prices: Facts, Perspectives, Impacts and Actions Required. HighLevel Conference on Food Security: The Challenges of Climate Change and Bioenergy. Rome, 3-5 June 2008. HLC/08/INF/1. Rome: FAO.

FAO. 2008i. The State of Food and Agriculture. Biofuels: Prospects, Risks and Opportunities. Rome: FAO.

FAO. 2008j. The State of Food and Agriculture in Asia and the Pacific Region. FAO, Bangkok.

FAO. 2009a. Making Sustainable Biofuels Work for Smallholder Farmers and Rural Households: Issues and Perspectives. Prepared by A. Rossi and Y. Lambrou. Rome: FAO.

FAO. 2009b. Round Table on the Bioenergy Rush: Opportunities and Risks for Food Security, the Environment and Rural Development. Twenty-ninth FAO Regional Conference for Asia and the Pacific. Bangkok, Thailand, 26-31 March 2009. APRC/08/7. Rome: FAO.

FAO. 2009c. Small-scale Bioenergy Initiatives: Brief Description and Preliminary Lessons on Livelihood Impacts from Case Studies in Asia, Latin America and Africa. Rome: FAO and PISCES.

FAO. 2009d. The Market and Food Security Implications of the Development of Biofuel Production. Committee on Commodity Problems, Sixty-seventh Session, Rome, 20-22 April 2009, FAO. CCP 09/6. 
FAO/GBEP. 2007. A Review of the Current State of Bioenergy Development in G8 +5

Countries. Rome: FAO.

FAO/IIED. 2008. Fuelling Exclusion? The Biofuels Boom and Poor People's Access to Land. Rome: FAO.

Frankhauser S., and R. S. J. Tol. 2005. On climate change and economic growth. Resource and Energy Economics 27: 1-17.

Gardner, B. 1996. European Agriculture: Policies, Production and Trade. London and New York: Routledge.

Gramsci, A. 1971. Selections from the Prison Notebook. Q Hoare and G Nowell Smith (eds and trans) London: Lawrence and Wishart.

Harvey, D. 1996. Justice, Nature \& the Geography of Difference. Oxford, UK: Blackwell Publishers.

Hedrén, J., and B-O. Linnér. 2009. Utopian thought and the politics of sustainable development. Futures 41: 210-219.

Heinimö J., V. Pakarinen, V. Ojanen, and T. Kässi. 2007. International Bioenergy Trade: Scenario Study on International Biomass Market in 2020. Lappeenranta University of Technology. IEA Bioenergy Task 40. Paris: IEA. 
Keohane, R. O. 1978. The International Energy Agency: State influence and transgovernmental politics. International Organization 32: 929-951.

Kuchler, M., and Linnér, B-O. 2012. Challenging the food vs. fuel dilemma: genealogical analysis of the biofuel discourse pursued by international organizations. Food Policy 37: 581588.

IEA. 1994. Biofuels. Energy and Environment Policy Analysis Series. Paris: IEA.

IEA. 1995. World Energy Outlook. Paris: OECD/IEA.

IEA. 1997a. Biomass Energy: Key Issues and Priority Needs. Conference proceedings, 3-5 February 1997, Paris.

IEA. 1997b. Key Issues in Developing Renewables. Paris: IEA.

IEA. 1998. Biomass Energy: Data, Analysis and Trends. Conference Proceedings, Paris, 2324 March 1998, IEA.

IEA. 1999. Automotive Fuels For the Future: The Search for Alternatives. IEA/AFIS, Paris.

IEA. 2000a. Energy Technology and Climate Change: A Call to Action. Paris: OECD/IEA.

IEA. 2000b. World Energy Outlook. Paris: OECD/IEA.

IEA. 2001. World Energy Outlook. Paris: OECD/IEA. 
IEA. 2002. Transportation Projections in OECD Regions. Paris: IEA.

IEA. 2003a. Integrating Energy and Environmental Goals: Investment Needs and Technology Options. Paris: IEA.

IEA. 2003b. Transport Technologies and Policies for Energy Security and $\mathrm{CO}_{2}$ Reductions. IEA Energy Technology Policy \& Collaboration Papers. Paris: IEA.

IEA. 2004a. Biofuels for Transport: An International Perspective. Paris: IEA.

IEA. 2004b. Energy Security and Climate Change Policy Interactions: An Assessment Framework. Paris: IEA.

IEA. 2004c. Reducing Oil Consumption in Transport: Combining Three Approaches. Prepared by L Fulton. Office of Energy Efficiency, Technology and R\&D, International Energy Agency. IEA/EETWorking Paper, EET/2004/01. Paris: IEA.

IEA. 2004d. Renewable Energy: Market \& Policy Trends in IEA Countries. Paris: OECD/IEA.

IEA. 2004e. World Energy Outlook. Paris: OECD/IEA.

IEA. 2005. Deploying Climate-friendly Technologies through Collaboration with Developing Countries. Paris: IEA. 
IEA. 2006a. Environmental and Energy Products: The Benefits of Liberalising Trade. Paris: OECD/IEA.

IEA. 2006b. Renewable Energy: RD\&D Priorities: Insights from IEA Technology Programmes. Paris: IEA.

IEA. 2006c. World Energy Outlook. Paris: OECD/IEA.

IEA. 2007a. Bioenergy Project Development \& Biomass Supply. Paris: OECD/IEA.

IEA. 2007b. Renewables in Global Energy Supply: An IEA Fact Sheet. Paris: OECD/IEA.

IEA. 2008a. From 1st- to 2nd-generation Biofuel Technologies: An Overview of Current Industry and R\&D Activities. Paris: OECD/IEA.

IEA. 2008b. World Energy Outlook. Paris: OECD/IEA.

IEA. 2009. World Energy Outlook. Paris: OECD/IEA.

IEA. 2010. World Energy Outlook. Paris: OECD/IEA.

IEA Bioenergy. 1998. The Role of Bioenergy in Greenhouse Gas Mitigation. IEA Bioenergy Task 25. Graz, Austria: JOANNEUM RESEARCH Forschungsgesellschaft mbH. 
IEA Bioenergy. 2002. Delivering the Bioenergy Triple Bottom Line to the Global Community.

Prepared by E. H. Ralph, R. E. H. Sims, and K. M. Richards. A Report to IEA Bioenergy Task 29. Paris: IEA.

IEA Bioenergy. 2004. Ethanol from Lignocellulosics: Views to Implementation. Prepared by

W. E. Mabee, D. J. Gregg, and J. N. Saddler. A Report to IEA Bioenergy Task 39. Paris: IEA.

IEA Bioenergy. 2005a. Ethanol from Lignocellulosics: Policy Options to Support Bioethanol

Production. W. E. Mabee, and J. N. Saddler. A Report to IEA Bioenergy Task 39. Paris: IEA.

IEA Bioenergy. 2005b. Options for trading bioenergy products and services. In B.

Schlamadinger, A. Faaij, M. Junginger, S. Woess-Gallasch, and E. Daugherty (eds.) IEA

Bioenergy Annual Report 2005. Paris: IEA.

IEA Bioenergy. 2006a. Ethanol from Lignocellulosics: Comparing Biofuel Technology

Options. Prepared by W. E. Mabee, and J. N. Saddler. A Report to IEA Bioenergy Task 39.

Paris: IEA.

IEA Bioenergy. 2006b. Opportunities and Barriers for Sustainable International Bioenergy

Trade and Strategies to Overcome Them. Prepared by M. Junginger, A. Faaij, P-P.

Schouwenberg, C. Arthers, D. Bradley, G. Best, J. Heinimö, B. Hektor, P. Horstink, A.

Grassi, K. Kwant, Ø. Leistad, E. Ling, M. Peksa, T. Ranta, F. Rosillo-Calle, Y. Ryckmans, M.

Wagener, A. Walter, and J. Woods. IEA Bioenergy Task 40. Paris: IEA. 
IEA Bioenergy. 2006c. Overview of Recent Developments in Sustainable Biomass

Certification. Prepared by J. van Dam, M. Junginger, A. Faaij, I. Jürgens, G. Best, and U. Fritsche. A Report to IEA Bioenergy Task 40. Paris: IEA.

IEA Bioenergy. 2006d. Second Generation Biofuels: A Review from a Market Barrier Perspective. Prepared by $(\text { S\&T) })^{2}$ Consultants Inc. IEA Bioenergy Task 39, Canada.

IEA Bioenergy. 2006e. Sustainable International Bioenergy Trade: Securing Supply and Demand. IEA Bioenergy Task 40. Paris: IEA.

IEA Bioenergy. 2007. Market Evaluation: Fuel Ethanol. IEA Bioenergy Task 40. Paris: IEA.

IEA Bioenergy. 2008a. Biofuels for Transport: Part of a Sustainable Future? Summary and Conclusions from the IEA Bioenergy ExCo61 Workshop. IEA Bioenergy: ExCo: 2008:04. Paris: IEA.

IEA Bioenergy. 2008b. Synergies and Competition in Bioenergy Systems. IEA Bioenergy Task 41. Paris: IEA.

IIER. 2011. Low Carbon and Economic Growth: Key Challenges. Prepared by H. Kunz, R. Koppelaar, T. Raettig, and S. Balogh. Meilen, Switzerland: Institute for Integrated Economic Research.

IPCC. 1990. Climate Change: The IPCC Response Strategies. Report prepared for Intergovernmental Panel on Climate Change by Working Group III. Geneva: IPCC/WMO. 
IPCC. 1995. IPCC Second Assessment: Climate Change 1995. Intergovernmental Panel on Climate Change. Geneva: IPCC/WMO.

IPCC. 2001a. Climate Change 2001: Impacts, Adaptation, and Vulnerability. J. J. McCarthy, O. F. Canziani, N. A. Leary, D. J. Dokken, and K. S. White (eds.) Contribution of Working Group II to the Third Assessment Report of the Intergovernmental Panel on Climate Change. Cambridge, UK and New York: Cambridge University Press.

IPCC. 2001b. Climate Change 2001: Mitigation. B. Metz, O. Davidson, R. Swart, and J. Pan (eds.) Contribution of Working Group III to the Third Assessment Report of the Intergovernmental Panel on Climate Change. Cambridge, UK and New York: Cambridge University Press.

IPCC. 2001c. Climate Change 2001: Synthesis Report. R. T. Watson and the Core Writing Team (eds.) Contribution of Working Groups I, II, and III to the Third Assessment Report of the Intergovernmental Panel on Climate Change. Cambridge, UK and New York: Cambridge University Press.

IPCC. 2001d. Climate Change 2001: The Scientific Basis. J. T. Houghton, Y. Ding, D. J. Griggs, M. Noguer, P. J. van der Linden, X. Dai, K. Maskell, and C. A. Johnson (eds.) Contribution of Working Group I to the Third Assessment Report of the Intergovernmental Panel on Climate Change. Cambridge, UK and New York: Cambridge University Press. 
IPCC. 2001e. Summary for Policy Makers. In B. Metz, O. Davidson, R. Swart, and J. Pan (eds.) Climate Change 2001: Mitigation. Contribution of Working Group III to the Third Assessment Report of the Intergovernmental Panel on Climate Change. Cambridge, UK and New York: Cambridge University Press.

IPCC. 2001f. Technical Summary. In B. Metz, O. Davidson, R. Swart and J. Pan (eds.)

Climate Change 2001: Mitigation. Contribution of Working Group III to the Third Assessment Report of the Intergovernmental Panel on Climate Change. Cambridge, UK and New York: Cambridge University Press.

IPCC. 2007a. Climate Change 2007: Impacts, Adaptation and Vulnerability. M. L. Parry, O. F. Canziani, J. P. Palutikof, P. J. van der Linden, and C. E. Hanson (eds.) Contribution of Working Group II to the Fourth Assessment Report of the Intergovernmental Panel on Climate Change. Cambridge, UK: Cambridge University Press.

IPCC. 2007b. Climate Change 2007: Mitigation. B. Metz, O. R. Davidson, P. R. Bosch, R. Dave, and L. A. Meyer (eds.) Contribution of Working Group III to the Fourth Assessment Report of the Intergovernmental Panel on Climate Change. Cambridge, UK and New York: Cambridge University Press.

IPCC. 2007c. Climate Change 2007: Synthesis Report. Core Writing Team, R. K. Pachauri, and A. Reisinger (eds.) Contribution of Working Groups I, II and III to the Fourth Assessment Report of the Intergovernmental Panel on Climate Change. Cambridge, UK: Cambridge University Press. 
IPCC. 2007d. Summary for Policymakers. In B. Metz, O. R. Davidson, P. R. Bosch, R. Dave, and L. A. Meyer (eds.) Climate Change 2007: Mitigation. Contribution of Working Group III to the Fourth Assessment Report of the Intergovernmental Panel on Climate Change. Cambridge, UK and New York: Cambridge University Press.

IPCC. 2007e. Technical Summary. In B. Metz, O. R. Davidson, P. R. Bosch, R. Dave, and L. A. Meyer (eds.) Climate Change 2007: Mitigation. Contribution of Working Group III to the Fourth Assessment Report of the Intergovernmental Panel on Climate Change. Cambridge, UK and New York: Cambridge University Press.

Johnston, B. F., and J. W. Mellor. 1961. The role of agriculture in economic development. The American Economic Review 51: 566-593.

Jørgensen, M., and L. Phillips. 2002. Discourse Analysis as Theory and Method. London, Thousand Oaks, New Delhi: Sage Publications.

Junginger, M., J. van Dam, S. Zarrilli, F. Ali Mohamed, D. Marchal, A. Faaij. 2010. Opportunities and Barriers for International Bioenergy Trade. IEA Bioenergy Task 40. Paris: IEA.

Laclau, E. 1993. Politics and the limits of modernity. In T. Docherty (ed) Postmodernism: A reader, pp. 329-343. London: Harvester Wheatsheaf.

Laclau, E. 1996. Emancipation(s). London and New York: Verso. 
Laclau, E. 2000. Constructing Universality. In J. Butler, E. Laclau, S. Žižek (eds) Contingency Hegemony, Universality. London, New York: Verso, pp. 281-307.

Laclau, E., and C. Mouffe. 2001. Hegemony and Socialist Strategy: Towards a Radical Democratic Politics, 2nd ed. London, New York: Verso.

Newell, P. 2012. Globalization and the Environment: Capitalism, Ecology and Power. Polity Press, Cambridge, UK.

OECD/FAO. 2007. Agricultural Outlook 2007-2016. Rome: FAO.

Phillips, R. W. 1960. Food and Agriculture Organization completes 15 years. Science 132: $871-881$.

Podobnik, B. 2006. Global Energy Shifts: Fostering Sustainability in a Turbulent Age. Philadelphia, PA: Temple University Press.

Rapsomanikis, G., and D. Hallam. 2006. Threshold Cointegration in the Sugar Ethanol-Oil Price System in Brazil: Evidence from Nonlinear Vector Error Correction Models. FAO Commodity and Trade Policy Research Working Paper No.22. Rome: FAO.

Rogers Jr., W. M. 2000. Third Millennium Capitalism: Convergence of Economic, Energy and Environmental Forces. Westport, CT and London, UK: Quorum. 
Schmidhuber, J. 2006. Impact of an increased biomass use on agricultural markets, prices and food security: A longer-term perspective. Paper prepared for the International symposium of Notre Europe, Paris, 27-29 November 2006.

Sekulova, F., Kallis, G., Rodríguez-Labajos, B., Schneider, F. 2013. Degrowth: from theory to practice. Journal of Cleaner Production 38: 1-6.

Smith, A. M. 1998. Laclau and Mouffe: The Radical Democratic Imaginary. London and New York: Routledge.

Southgate, D., D. H. Graham, and L. Tweeten. 2011. The World Food Economy. Danvers, MA: John Wiley \& Sons.

Steenblik, R. 2007. Biofuels - At What Cost? Government support for ethanol and biodiesel in selected OECD countries. Geneva: GSI \& IISD.

Stern, D. I. 2010. The Role of Energy in Economic Growth. CCEP working paper 3.10. Canberra: Centre for Climate Economics \& Policy, Crawford School of Economics and Government, The Australian National University.

Stern, N. 2006. Stern Review: The Economics of Climate Change. London: HM Treasury.

WEC/FAO. 1999. The Challenge of Rural Energy Poverty in Developing Countries. London: World Energy Council. 
Weis, T. 2007. The Global food economy: the battle for the future of farming. Zed Books, London and New York.

WorldWatch Insitute. 2007. Biofuels for Transport: Global potential and implications for sustainable energy agriculture. London, UK: Eearthscan. 